\title{
Contrasts of esophageal-fistula versus bite-count techniques to determine cattle diets
}

\author{
ISAAC M. ORTEGA, FRED C. BRYANT AND D. LYNN DRAWE
}

\begin{abstract}
Authors are research associate, professor, and assistant director, Department of Range and Wildlife Management,
\end{abstract} Texas Tech University, Lubbock 79409-2125 and Welder Wildlife Foundation, P.O. Box 1400, Sinton 78387.

\begin{abstract}
To understand how different techniques might affect diet estimates for cattle, the esophageal-fistula and bite-count techniques were compared using trained cattle. For the Texas Coastal Bend, bite-count was not as reliable a technique as the esophageal fistula. These techniques differed in estimation of forage classes and plant species in cattle diets. The esophageal-fistula technique was more accurate however, the bite-count technique may be acceptable if analyses are limited to only those plant species making up $>2 \%$ of the diet.
\end{abstract}

Key Words: microhistological analysis, grazing, cattle, Texas Coastal Bend

Techniques such as fecal analysis, forage utilization, stomach analysis, esophageal and rumen fistulae, and direct observation have been used to determine diets of free-ranging ungulates (Holechek et al. 1982). Among these techniques, examination of esophageal estrusa was the most accurate method to determine food habits of ungulates (McInnis 1976, McInnis et al. 1983). This technique has been extensively used to determine food habits of livestock since first descibed by Torrell (1954). However, it has not been widely used with wild ungulates (Kessler et al. 1981) primarily because the stress involved when using semi-tame animals limits its efficacy (Short 1962, Veteto et al. 1972). This is the reason why bite count has proven more useful for tame white-tailed deer (Odocoileus virginianus Boddaert) (Bryant et al. 1979, Thill and Martin 1989) and tame mule deer (Odocoileus hemionus Rafinesque) (Olson-Rutz and Urness 1987). Bite-count has also been used in domestic livestock research (Frasure 1979, Sanders et al. 1980).

Free et al. (1971), working in a semi-arid Colorado environment, found that bite-count and esophageal-fistula methods gave similar estimates of cattle diets. When using these techniques,

\footnotetext{
The authors wish to express gratitude to I. Berger and D. Van Noy for assistance in microhistological analysis and to S. Soltero-Gardea for his help in the field. We also wish to thank $C$. Britton, $K$. Launchbaugh, and $E$. Laca for reviews of the manuseript. This is a Welder Wildlife Foundation contribution No. 445 and a College of Agriculture and Natural Resources TTU publication T-9-704. This research was also supported by the Office of Agriculture, Bureau of Research and Development, U.S. Agency for International Development under Grant No. DAN-1328-G-00-0046-00.

Manuscript accepted 11 Mar. 1995.
}

they suggested that reliable estimates depended primarily upon observer skill although other parameters such as density and diversity of plants also affected diet estimation. Since no comparison of esophageal-fistula and bite-count techniques have been conducted in diverse and rich vegetation types such as those found in the Texas Coastal Bend, our objective was to determine the botanical similarity of cattle diets estimated by esophageal and bite-count techniques.

\section{Materials and Methods}

The study was conducted at the Rob and Bessie Welder Wildlife Refuge, San Patricio County, Tex. The 1.7-ha pasture used for this experiment was characterized as a mesquite-mixedgrass community, dominated by grasses such as buffalograss (Buchloe dactyloides (Nutt.) Engelm), longtom (Paspalum lividum Trin.), and little bluestem (Schizachyrium scoparium (Michx.) Nash). Prairie coneflower (Ratibida columnaris (Sims) D. Don) and clay violet (Ruellia nudiflora (Gray) Urban) were the dominant forbs, though wood-sorrel (Oxalis dillenii Jacq) also occurred in patches. Measurements of vegetation were not conducted since only comparisons of diet sampling techniques were of interest. Botanical names and plant identification followed taxonomy by Gould and Box (1965) and Jones (1982).

A total of $\mathbf{9 0}$ samples of cattle diets was collected in August, October, and November, 1988, and February, May, and July, 1989. Diet samples were obtained from 5 randomly-selected, esophageally-fistulated steers from a herd of 12. Extrusa sample collection and bite-count observation were conducted simultaneously 3 to 4 consecutive days per month. To increase appetite of the steers, food and water were withheld for at least 12 hours the night before sampling. Diet data were collected in the early morning. Steers were fitted with collection bags and allowed to roam free in the pasture while an observer stood within 1 to $4 \mathrm{~m}$ of each steer and recorded the number of bites of each species. Steers were sequentially observed feeding for 25 bites until a minimum of 100 bites per steer were recorded. Selection of plant parts was not recorded. Data were recorded on cassette tape and transcribed to a computer. All bite-count data were recorded by the same observer.

Extrusa samples were allowed to drain in screen-bottom collection bags for at least 2 hours. A subsample of the diet was preserved in ethyl alcohol and prepared for microhistological analy- 
sis according to Scott and Dahl (1980). An aliquot of each sample was mounted on 5 microscope slides. From each slide, 20 fields were read to identify plant species based on a reference collection of plant specimens previously collected in the field. Frequency and percent composition were calculated following the method used by Scott and Dahl (1980). Analysis of botanical composition was conducted by 2 trained technicians at the Department of Range and Wildlife Management, Texas Tech University.

Species were pooled into 3 forage classes: forbs, grasses, and browse. Diet data were analyzed using the General Linear Model Procedure of the Statistical Analysis System (SAS 1985) for a completely randomized design with a split-plot in time arrangement. Replication was represented by animals. Techniques were whole plot with months as the split plot. The error term for testing significant effects of techniques was replication $\mathrm{X}$ techniques. Each estimated species or forage class mean obtained by bitecount was compared to that obtained by microhistological analysis of esophageal-fistula samples using Fisher's Protected Least Significant Difference at the $95 \%$ confidence level.

Shannon's diversity index (Magurran 1988) was determined for the vegetation of the area as well as for diets collected using the different techniques. Vegetation cover frequency was extrapolated from data collected in the immediate surrounding pastures for a different study (Ortega 1991). A t-test was used to compare diversity indices among vegetation and the diets (Hutchenson 1970). Diversity indices and t-tests were calculated using BIODIV (Baev and Penev 1993).

\section{Results}

Across sampling periods the 2 techniques were different $(P<0.05)$ in detecting forbs (bite-count $=11.4 \%$; esophageal-fistula $=17.7 \%$ ) and grasses (bite-count $=88 \%$; esophageal-fistula $=$ $81.2 \%$ ), but were similar $(P>0.05)$ in detecting browse (bitecount $=0.6 \%$; esophageal-fistula $=1.1 \%$ ) in the cattle diets. Each month, data collected using the bite-count technique tended to show a higher proportion of grasses and lower proportion of forbs than the esophageal-fistula method (Fig. 1). Both techniques detected differences $(P<0.05)$ in the amount of grasses and forbs in the diets each month (Fig. 1).

The number of plant species detected by either technique varied with sampling period (Table 1). Although more plant species were detected using the esophageal-fistula technique, most of them were detected only in trace amounts and probably were not an important contribution to cattle diets (Table 2). Overall, more forb and grass species were detected by the esophageal-fistula than with the bite-count method (Table 1). A total of 41 plant species were common in diets estimated by both techniques.

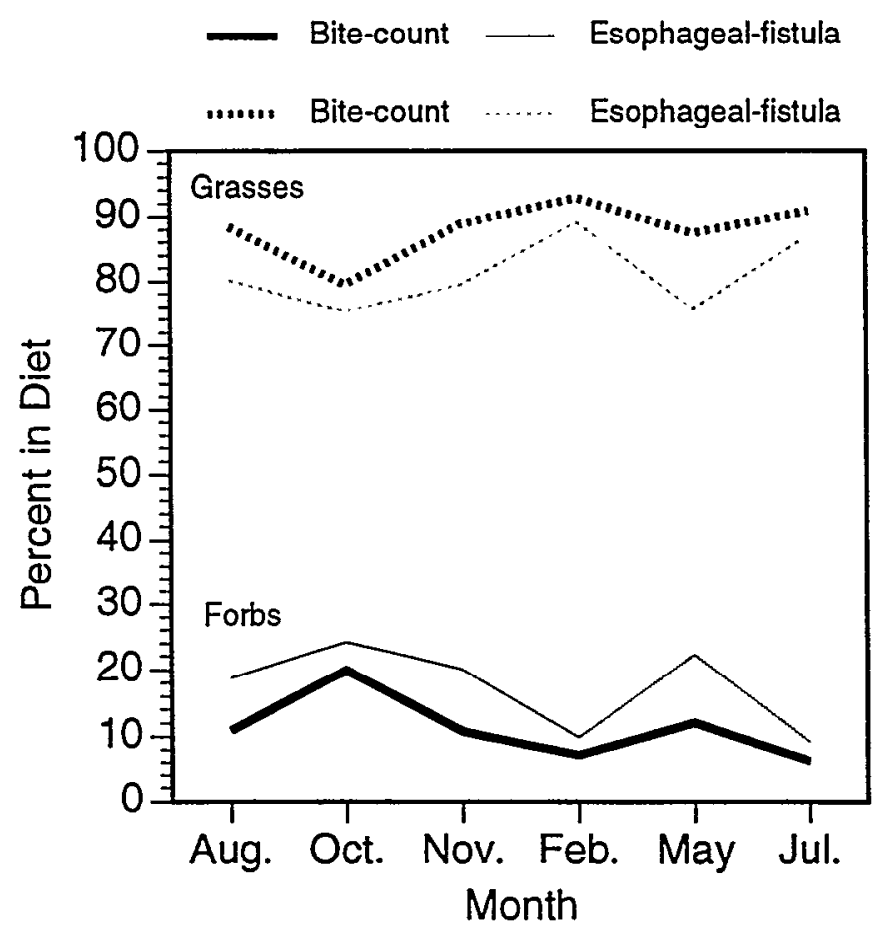

Fig. 1. Monthly cattle diets by forage class as determined by the bitecount and the esophageal-fistula techniques.

Overall, regardless of the technique, 13 species were detected in proportion greater than $2 \%$ of the diet, 5 were forbs and 8 were grasses. Considering only those species comprising more than $2 \%$ of the diet, $93 \%$ of the diet was accounted for by the bite-count method, while the esophageal-fistula method accounted for only 79\%. Among the most important forbs in the cattle diet, Oxalis dillenii was detected similarly $(P>0.05)$ by either technique (Table 2). Buchloe dactyloides and Schizachyrium scoparium were among the most important grasses used by cattle, however they were detected differently $(P<0.05)$ by the 2 techniques (Table 2). Almost twice as much $B$. dactyloides was detected using the bite-count technique compared to the esophageal-fistula technique (Table 2). Dichanthium annulatum (Forsk.) Stapf was the only grass detected similarly $(P>0.05)$ by the 2 techniques (Table 2).

The highest diversity index for vegetation was in October, when biomass was also the highest (Soltero-Gardea 1991) and lowest in July (Fig. 2). Both techniques had diet diversity indices that followed a similar trend, though lower. The bite-count indices, however were significantly different $(P<0.001)$ from vegetation indices for each month. Diversity of the diets collected by the esophageal-fistula technique was similar to the vegetation

Table 1. Number of plant species detected monthly using the bite-count (BC) and the esophageal-fistula (EF) methods.

\begin{tabular}{|c|c|c|c|c|c|c|c|c|c|c|c|c|c|c|}
\hline & \multicolumn{2}{|c|}{ August } & \multicolumn{2}{|c|}{ October } & \multicolumn{2}{|c|}{ November } & \multicolumn{2}{|c|}{ February } & \multicolumn{2}{|c|}{ May } & \multicolumn{2}{|c|}{ July } & \multicolumn{2}{|c|}{ Overall } \\
\hline & $\mathrm{BC}$ & $\mathrm{EF}$ & $\mathrm{BC}$ & $\mathrm{EF}$ & $\mathrm{BC}$ & $\mathbf{E F}$ & $\mathrm{BC}$ & $\mathrm{EF}$ & $\mathrm{BC}$ & EF & $\mathrm{BC}$ & $\mathrm{EF}$ & $\mathrm{BC}$ & EF \\
\hline & -- & -- & 8 & . & -- & . & ger & ies) & $\cdots$ & ---1 & $\ldots$ & $2-4$ & $-\cdots$ & $\cdots$ \\
\hline Forbs & 13 & 30 & 14 & 20 & 15 & 25 & 4 & 16 & 11 & 22 & 6 & 23 & 23 & 37 \\
\hline Grasses & 9 & 23 & 10 & 19 & 10 & 21 & 7 & 24 & 7 & 24 & 10 & 22 & 19 & 28 \\
\hline Browse & 1 & 5 & 0 & 0 & 1 & 2 & 0 & 2 & 2 & 3 & 2 & 4 & 3 & 7 \\
\hline TOTAL & 23 & 58 & 24 & 39 & 26 & 48 & 11 & 42 & 20 & 49 & 18 & 49 & 45 & 72 \\
\hline
\end{tabular}


Table 2. Relative frequency of plant species in monthly cattle diets using the bite-count (BC) and the esophageal-fistula (EF) methods ${ }^{1}$.

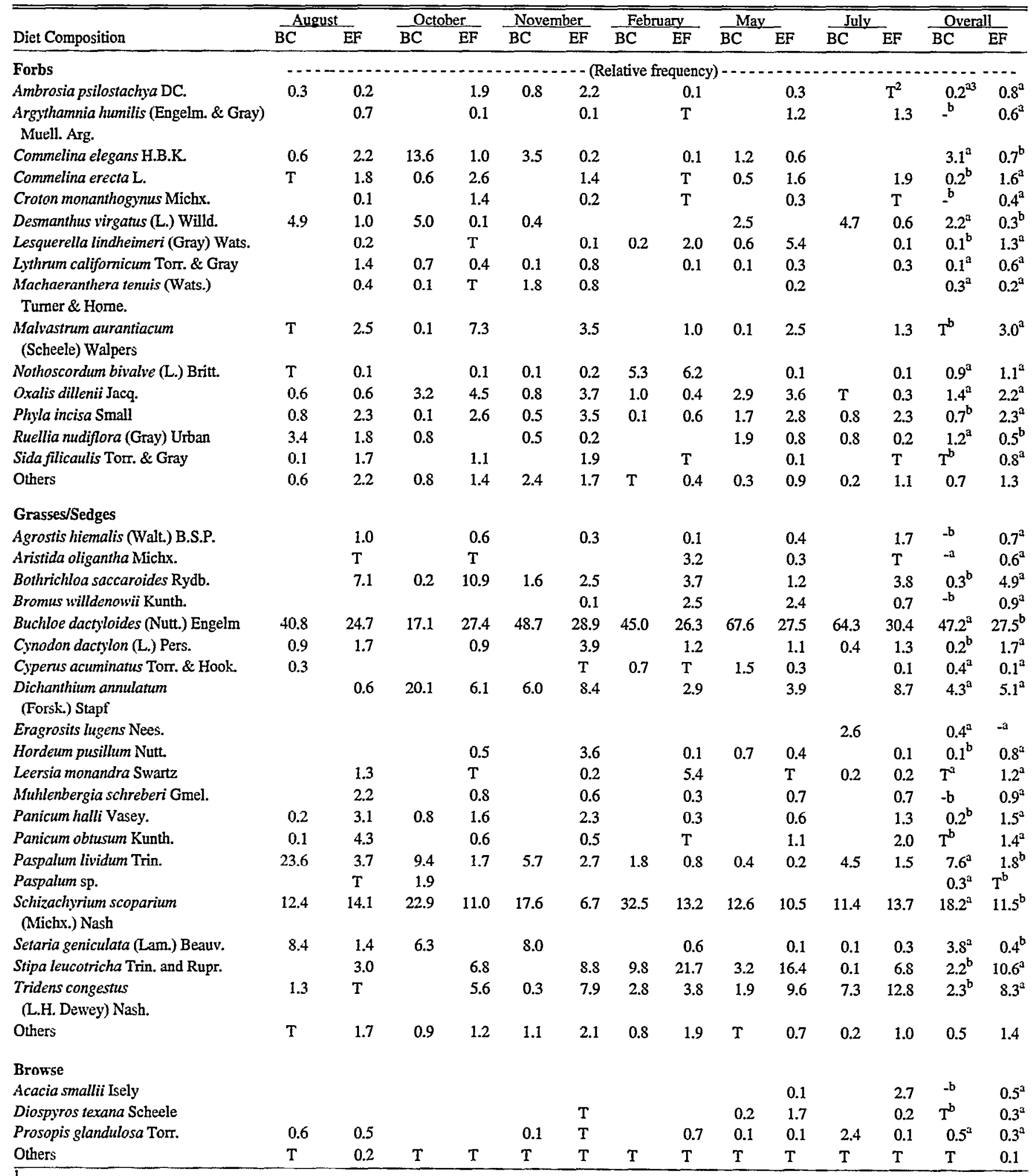

${ }_{2}$ Only spicics that contributed more than $1 \%$ on any sampled month are presented in this table.

${ }_{3} \mathrm{~T}=$ oicurrence of $>0.09 \%$.

${ }^{3}$ Means with the same superseript between columns are not significantly different $(P>0,05)$. 


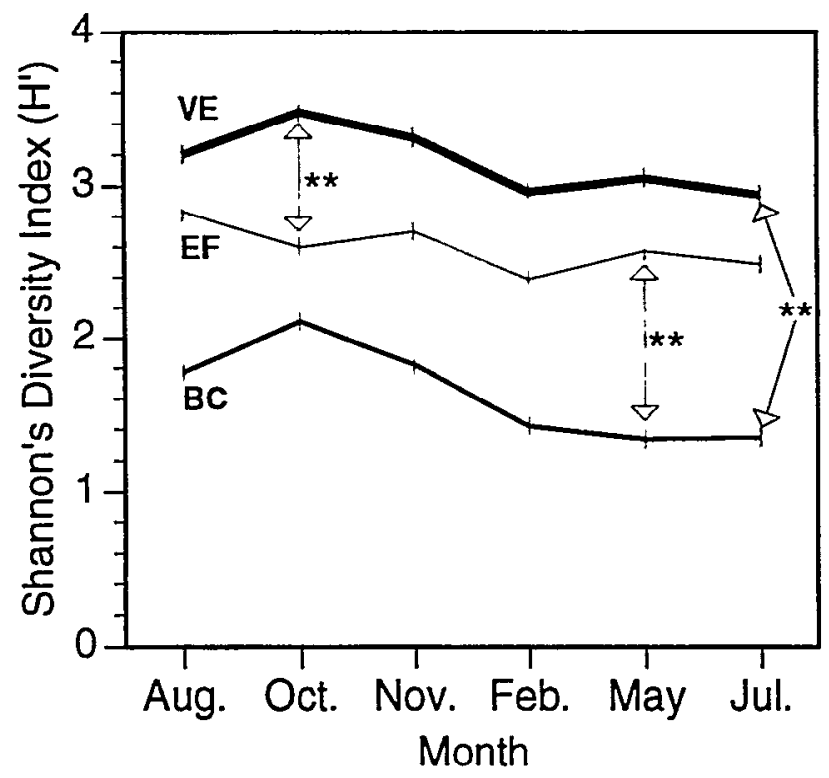

Fig. 2. Diversity indices of vegetation (VE) of the area, the bite-count (BC), and the esophageal-fistula (EF) techniques. $(* *=$ indices significantly different $(P<0.001)$.

for each month but October $(P<0.001$; Fig. 2$)$. Diversity between diets collected by each technique were similar in every month but May $(P<0.001$; Fig. 2$)$.

\section{Discussion}

McInnis (1976) and McInnis et al. (1983) found that the most accurate method to determine food habits of ungulates was esophageal-fistula. In our study, diets obtained by bite-count had fewer plant species when compared to esophageal-fistula. Also, forbs were estimated in lower proportions using the bite-count method compared to the esophageal-fistual method.

On the Welder Wildlife Refuge, density and diversity of plant species was high, making positive identification by bite-count of cattle diets difficult. Even so, plant species were identified easily because the bite-count observations were conducted $1-4 \mathrm{~m}$ from the animal. However, a potential problem when using bite-count to obtain cattle diets relates to the way cattle consume vegetation. Inaccurate observation of the plant species being eaten by cattle can be related to the wide mouth and the sweeping prehension movements of the tongue of these animals. In dense, diverse vegetation, several plant species can be taken in one bite for which the observer will be able to see only the most obvious species; e.g., the long blades of grasses or large, broad leaves of some forbs. For a narrow-mouth species such as deer, species composition may be easily observed. Thus, vegetational complexity and cattle grazing behavior may help explain why fewer plant species were detected and forbs were apparently underestimated using bite-count compared to esophageal-fistula. This seems to be confirmed by the diversity indices. Diversity of diets collected with either technique followed the trend in diversity of the vegetation, although with lower diversities, especially with the bite-count technique. However, diets collected by the esophageal-fistula fol- lowed the diversity of the vegetation much closer than the bitecount technique.

Reliable diet estimates would depend on observer skill in a complex plant community (Free et al. 1971). Our study was conducted by a single observer who had several months of experience with the local flora. Thus, observer error was minimized.

When only plant species contributing greater than $2.0 \%$ of the diet were examined, the bite-count diets contained a greater proportion of those species in the esophageal-fistula diets. Thus the bite-count technique may be acceptable if analyses are limited to only those plant species making up $>2.0 \%$ of the diet.

In summary, the bite-count and esophageal-fistula techniques to determine cattle diets in the Texas Coastal Bend gave different results for forage classes and plant species ingested by cattle. Grasses, the main forage class used by cattle, were detected differently by the 2 techniques $(P<0.05)$. The bite-count technique detected grasses in greater proportion than the esophageal-fistula technique. This was especially true of the 2 most important dietary constituents, Buchloe dactyloides and Schizachyrium scoparium. These results were related to the high density and diversity of the vegetation community at the Welder Wildlife Refuge and to the ingestion mechanism of cattle.

Either technique has its advantages and disadvantages depending upon the environment, the level of resolution required, and thc animal specics being used. In the Texas Coastal Bend, the esophageal-fistula method should be used when information on floral diversity or botanical composition of cattle diets is needed. Research using the bite-count method for cattle diets could report data as forage classes, as long as researchers recognize that bitecount overestimates grasses and underestimates forbs. Still, the bite-count method provides a reasonable estimate of forage classes consumed by cattle throughout the year. Further, if only species comprising greater than $2 \%$ of the diet are included, the bite-count technique will estimate a greater percentage of the diet than the esophageal-fistula technique.

\section{Literature Cited}

Baev, P.V., and L.D. Penev. 1993. BIODIV. Program for calculating biological diversity parameters, similarity, niche overlap, and cluster analysis. Pensoft and Exeter Software.

Bryant, F.C., M.M. Kothmann, and L.B. Merrill. 1979. Diets of sheep, Angora goats, Spanish goats and white-tailed deer under excellent range conditions. J. Range Manage. 32:412-417.

Frasure, J.R. 1979. The effects of three grazing management systems on cattle diets on the Welder Wildlife Refuge. M.S. Thesis. Texas Tech Univ., Lubbock, Tex.

Free, J.C., P.L. Sims, and R.M. Hansen. 1971. Methods of estimating dry-weight composition in diets of steers. J. Anim. Sci. 32:1003-1008.

Gould, F.W., and T.W. Box. 1965. Grasses of the Texas Coastal Bend. Texas A\&M Univ., College Station, Tex.

Holechek, J.L., M. Vavra, and R.D. Pieper. 1982. Botanical composition determination of range herbivore diets: a review. J. Range Manage. 35:309-315.

Hutchenson, K. 1970. A test for comparing diversities based on Shannon's formula. J. Theor. Biol. 29:151-154.

Jones, F.B. 1982. Flora of the Texas Coastal Bend. Welder Wildlife Foundation. Mission Press, Corpus Christi, Tex.

Kessler, W.B., W.F. Kasworm, and W.L. Bodie. 1981. Three methods compared for analysis of pronghorn diets. J. Wildl. Manage. 45:612-619.

Magurran, A.E. 1988. Ecology diversity and its measurements. Princeton Univ. Press. Princeton, N.J. 
McInnis, M.L. 1976. A comparison of four methods used in determining the diets of large herbivores. M.S. Thesis. Oregon State Univ. Corvallis, Ore.

McInnis, M.L., M. Vavra, and W.C. Krueger. 1983. A comparison of four methods used to determine the diets of large herbivores. J. Range Managc. 36:302-306.

Olson-Rutz, K.M., and P.J. Urness. 1987. Comparability of behavior and diet selection of tractable and wild mule deer. Utah Dept. Natur. Res. Pub. No. 88-3.

Ortega, L.M. 1991. Deer and cattle foraging strategies under different grazing systems and stocking rates. Ph.D. Diss., Texas Tech Univ., Lubbock, Tex.

Sanders, K.D., B.E. Dahl, and G. Scott. 1980. Bite-count vs. fecal analysis for range animal diets. J. Range Manage. 33:146-149.

SAS. 1985. SAS User's Guide: Statistics, Version 5 Edition. SAS Insitiute Inc. Cary, N.C.
Scott, G., and B.E. Dahl. 1980. Key to selected plant species of Texas using plant fragments. Occasional Papers, The Museum, Texas Tech Univ., Lubbock, Tex.

Short, H.L. 1962. The use of a rumen fistula in a white-tailed deer. J. Wildl. Manage. 26:341-342.

Soltero-Gardea, S. 1991. Phytomass dynamics and deer and cattle nutrition under different grazing practices in the Texas Coastal Bend. Ph.D. Diss., Texas Tech Univ., Lubbock, Tex.

Thill, R.E., and A. Martin. 1989. Deer and cattle diets on heavily grazed pine-bluestem range. J. Wildl. Manage. 53:540-548.

Torrell, D.T. 1954. An esophageal-fistula for animal nutrition studies. J. Anim. Sci. 13:878-882.

Veteto, G., C.E. Davis, R. Hart, and R.M. Robinson. 1972. An esophageal cannula for white-tailed deer. J. Wildl. Manage. $36: 906-912$. 